\title{
Une éthique éditoriale et une intégrité scientifique au service du Sud
}

Jacques TASSIN

Au-delà de ses spécificités thématiques ou partenariales, la revue Bois et Forêts des Tropiques poursuit une ambition qui est chère à son équipe éditoriale et à l'établissement qui l'héberge. Elle promeut la publication de résultats d'une recherche collaborative qui soit (i) produite avec des chercheurs du Sud, (ii) appliquée au développement du Sud, (iii) et donc accessible aux professionnels du Sud. Ce dénominateur commun tient de l'éthique du Cirad, dont l'acronyme nous rappelle qu'il s'agit bien de faire valoir une Coopération Internationale en Recherche Agronomique pour le Développement. Voilà qui ne peut être sans lien avec l'attachement de notre revue au respect de l'intégrité scientifique, cette forme de conduite intègre et honnête appelée à présider dans toute activité scientifique, en tant que condition de la qualité de la connaissance produite.

Nous gardons en effet l'ambition de promouvoir la reconnaissance internationale de la recherche conduite au Sud et, du mieux possible, par le Sud. Nous nous appliquons à aider de jeunes chercheurs du Sud, parfois peu expérimentés, à se familiariser avec l'exercice normatif et exigeant de la publication scientifique. Les articles rédigés par des scientifiques dont le patronyme renvoie à un pays déshérité ont, nous le savons, moins de chances d'être lus, puis d'être cités par leurs pairs des pays mieux lotis (Harris et al., 2017). Notre revue est en outre tenue de surnager dans un océan hypercompétitif, où les logiques éditoriales, sous-tendues par des logiques commerciales, accordent peu de crédit aux revues scientifiques qui, contre vents et marées, s'attachent à faire valoir la reconnaissance des chercheurs démunis. En dépit de ces contraintes que nous estimons plutôt absurdes, nous ne perdons pas de vue nos attachements aux valeurs qui fondent notre établissement. Voilà pour notre éthique.

Mais défendre une telle éthique, c'est aussi devoir défendre l'intégrité scientifique. Dans la logique d'excellence qui prévaut actuellement dans la communauté de recherche, selon les déterminants en cours des évolutions de carrière et selon les indices les plus conventionnels de l'évaluation de la recherche, exagérément quantitatifs, nous savons que les revues de recherche appliquée au développement ne sont pas les mieux considérées. Nous n'ignorons pas cependant que le Cirad est signataire de la convention Dora sur l'évaluation de la recherche, qui défend le principe de ne plus utiliser les métriques de revues, tel le facteur d'impact, pour mesurer la qualité des articles de recherche ou pour évaluer les contributions d'un chercheur à la production de connaissances. L'objet de Bois et Forêts des Tropiques n'est assurément pas, selon une logique comptable, d'enrichir et de faire fructifier un capital éditorial. Il est de diffuser des résultats de recherche susceptibles d'impacter favorablement le développement. Nous sommes fiers de disposer d'un facteur d'impact, mais nous ne nous leurrons pas sur les valeurs qu'un tel indice engage (Seglen, 1997).

Nous restons profondément attachés à l'éthique collaborative qui est la raison d'être d'une revue scientifique du Cirad. La défense de cette éthique collaborative n'est, certes, pas toujours aisée. Les chercheurs du Nord comme du Sud, pressés par des injonctions sociales qui mériteraient d'être mieux analysées, se sentent voués à plus publier plutôt qu'à mieux publier, et cèdent alors parfois à des mirages malmenant leur propre intégrité scientifique. Les inconduites scientifiques sont devenues, nous n'en sommes pas dupes, une stratégie de survie au sein d'organismes de recherche de plus en plus sélectifs, voire de notoriété virtuelle, au Nord comme au Sud. Ne nous attardons pas sur de telles dérives qui, nous sommes bien placés pour le savoir, se multiplient année après année, sous des formes de plus en plus diverses : recours au plagiat, fabrication ou falsification de données, oubli ou ajout d'un auteur non consulté, signatures de complaisance, émiettement des publications, manipulations statistiques, filtrage des références bibliographiques, etc. Autant de raisons de refuser une partie des manuscrits qui nous parviennent, pour des raisons qui nous laissent alors plutôt amers, mais nous conduisent à nous montrer très fermes, car l'intégrité scientifique ne se discute pas (Corvol, 2016).

Notre cap reste inchangé. Nous défendons le principe d'une revue gratuite, accessible à tous, préservée des logiques éditoriales de marché. Nous sommes fiers d'appartenir à un établissement qui ne mâche pas ses mots à l'égard des revues prédatrices qui se nourrissent des dérives de la recherche scientifique. Et nous sommes particulièrement heureux de constater que les chercheurs du Sud se mobilisent tout autant contre ces pratiques prédatrices désastreuses, aussi trompeuses que condamnables, auxquelles ils se savent particulièrement exposés, ainsi que le révèle cette étude cinglante, mais ô combien saine, de Matumba et al. (2019).

Il y a plus de vingt-cinq ans, le sociologue canadien Serge Larivée, auteur d'un rapport sur la fraude scientifique, avait déjà parfaitement entrevu les conséquences délétères d'une éthique scientifique négligente (Larivée et Baruffaldi, 1992) : «Il s'en faudrait peut-être de peu, particulièrement en période de récession, pour que les payeurs de taxes, influencés par la couverture journalistique sensationnaliste de quelques cas célèbres, contestent la masse budgétaire impartie à la recherche scientifique dans tel ou tel domaine ou même dans son ensemble. » Voilà qui nous invite à veiller plus attentivement encore à ce qu'en conformité avec le mandat de notre établissement, et au respect d'une éthique que nous défendons activement, notre belle revue ciradienne demeure autant collaborative qu'intègre. 


\section{Editorial ethics and scientific integrity to serve the interests of the South}

Jacques TAssin

Over and above the aspects that relate specifically to our topic areas and partnerships, our work at Bois et Forêts des Tropiques pursues an aim to which our editorial team and our host organisation attach particular importance. Our journal promotes the publication of results from collaborative research that are (i) produced with researchers from the South, (ii) applied to development in the South, and (iii) can therefore be accessed by professionals in the South. The common denominator stems from the ethics of the Cirad, which is the acronym for Coopération Internationale en Recherche Agronomique pour le Développement - or Agricultural Research Centre for Development to give its English name. The link is clear with our journal's concern for scientific integrity - the term that refers to the honest and principled conduct that should govern every scientific endeavour as a prerequisite for the quality of the knowledge produced.

Our consistent ambition is to promote international recognition of research conducted in the South and, insofar as possible, by the South. We make every effort to help young researchers from the South, who sometimes have little experience, to become familiar with the demanding standards of scientific publishing. We know that articles published by scientists whose names evoke a disadvantaged country are less likely to be read and cited by their peers in wealthier countries (Harris et al., 2017). Our journal, moreover, has to sink or swim in a hyper-competitive environment in which editorial lines with an underlying business logic give little credit to scientific journals that persist in battling the odds to gain recognition for disadvantaged researchers. Despite these constraints - which we believe to be absurd - we have never lost our attachment to the values that underpin the activities of our organisation. This, then, summarises our ethical position.

But upholding this ethical position also means upholding scientific integrity. We know that given the prevailing logic of excellence in the research community, with the career prospects it currently determines and its highly normalised and excessively quantitative research assessment criteria, journals publishing research applied to development are not the most highly regarded. We are also well aware that the Cirad has signed the Dora agreement on research assessments, which upholds the principle that journal metrics, such as the impact factor, should no longer be used to measure the quality of research articles or to assess a researcher's contributions to knowledge production. Bois et Forêts des Tropiques is not in the business of seeking to enrich its editorial capital for profit: our aim is to disseminate the results of research that can have a positive impact on development. We are proud of the impact factor that we have, but we harbour no illusions as to the values conveyed by an index of this kind (Seglen, 1997).

We remain deeply attached to the collaborative ethics that underpin the existence of a Cirad journal, but upholding these collaborative ethics is not always easy. Researchers from both North and South, pressured by injunctions from society that deserve better analysis, feel obliged to publish more rather than to publish better, and sometimes succumb to the temptations of a mirage that will compromise their scientific integrity. Improper scientific conduct, as we are well aware, has become a strategy for survival in increasingly selective research organisations, and even for acquiring online reputations, in both North and South. We do not wish to elaborate on such abuses, which, as we know from first-hand experience, are increasing year by year in ever more diverse forms: plagiarism, fabricated or falsified data, omission or addition of authors who have not been consulted, grace-and-favour endorsements, piecemeal publications, statistical manipulations, filtered bibliographical references, etc. All these are reasons for rejecting some of the manuscripts we receive, and, bitter as this leaves us, it strengthens our resolve, because scientific integrity is not open to discussion (Corvol, 2016).

Our course stays unchanged. We uphold the principle of a publication which is available free of charge, accessible to all and free from the dictates of market-driven editorial policy. We are proud to work within an organisation that does not mince its words with regard to predatory journals that feed on abuses of scientific research. And we are more than glad to know that researchers from the South are taking up an equally strong stand against these disastrously deceitful and reprehensible practices to which they know they are particularly exposed, as revealed by the scathing but salutary study by Matumba et al. (2019).

More than twenty-five years ago, the Canadian sociologist Serge Larivée, the author of a report on scientific fraud, had already pointed to the pernicious effects of neglect for scientific ethics (Larivée et Baruffaldi, 1992): "it would not take much, especially in a time of economic recession, for taxpayers, under the influence of sensationalist press coverage of a few notorious cases, to start challenging the budgets allocated to scientific research, in particular fields or even in general". This is a consideration that prompts us, in fulfilling our organisation's mandate and actively upholding its ethical stance, to take ever more care to ensure that this Cirad journal we value so highly continues to be at once collaborative and principled.

\section{Una ética editorial y una integridad científica al servicio del Sur}

Jacques TASSIN

Más allá de las particularidades en cuanto a la temática o a las alianzas, la revista Bois et Forêts des Tropiques tiene una ambición muy apreciada por su equipo y por el establecimiento que la acoge. Promueve la publicación de resultados de una investigación colaborativa (i) producida con investigadores del Sur, (ii) aplicada al desarrollo del Sur, (iii) y, por lo tanto, accesible a los profesionales del Sur. Este denominador común proviene de la ética de Cirad, cuyo acrónimo nos recuerda que se trata de hacer valer una cooperación internacional en investigación agronómica para el desarrollo (Coopération Internationale en Recherche Agronomique pour le Développement). Esto no puede cumplirse sin el compromiso de nuestra revista hacia la integridad científica, la forma de conducta íntegra y honesta que debe presidir toda actividad científica, como condición de la calidad del conocimiento publicado. 
Mantenemos, efectivamente, la ambición de promover el reconocimiento internacional de la investigación llevada a cabo en el Sur y, de la mejor manera posible, por el Sur. Nos esforzamos por ayudar a jóvenes investigadores del Sur, a veces poco experimentados, a familiarizarse con el marco normativo y exigente de la publicación científica. Los artículos redactados por científicos cuyo apellido remite a un país desfavorecido tienen, lo sabemos, menos posibilidades de ser leídos y luego ser citados por sus iguales de países más favorecidos (Harris et al., 2017). Nuestra revista debe, además, pervivir en un océano hipercompetitivo, donde las lógicas editoriales, sostenidas por las lógicas comerciales, otorgan poco crédito a las revistas científicas que, contra viento y marea, se esmeran en hacer valer el reconocimiento de los investigadores poco conocidos. A pesar de estas limitaciones, que consideramos más bien absurdas, no perdemos de vista nuestra adhesión a los valores que identifican a nuestro establecimiento. Esto en referencia a nuestra ética.

Pero defender semejante ética también implica defender la integridad científica. En la lógica de la excelencia que predomina actualmente en la comunidad investigadora, según los determinantes en curso de las evoluciones de carrera y según los índices más convencionales de la evaluación de la investigación, exageradamente cuantitativos, sabemos que las revistas de investigación aplicada al desarrollo no son las mejor consideradas. No ignoramos, a pesar de ello, que Cirad es firmante de la convención Dora sobre la evaluación de la investigación, que defiende el principio de no utilizar más las métricas de revistas, como el factor de impacto, para medir la calidad de los artículos de investigación o para evaluar las contribuciones de un investigador en la producción de conocimiento. El objetivo de Bois et Forêts des Tropiques no es, por supuesto, enriquecer y hacer fructificar un capital editorial según una lógica contable. Su finalidad es difundir resultados de investigación susceptibles de impactar favorablemente en el desarrollo. Estamos orgullosos de disponer de un factor de impacto, pero no nos hacemos ilusiones sobre el valor que tal índice conlleva (Seglen, 1997).

Continuamos profundamente apegados a la ética colaborativa, que es la razón de ser de una revista científica de Cirad. La defensa de esta ética colaborativa no es, efectivamente, siempre fácil. Tanto los investigadores del Norte como del Sur, apremiados por las conminaciones sociales que deberían analizarse mejor, se sienten obligados a publicar más antes que a publicar mejor, y ceden a veces ante espejismos que llegan a poner en apuros su propia integridad científica. Las malas conductas científicas se han convertido, no seamos incautos, en una estrategia de supervivencia en el seno de organismos de investigación cada vez más selectivos, incluso de notoriedad virtual, tanto en el Norte como en el Sur. No nos demoremos en tales derivas que, tenemos una buena posición para saberlo, se multiplican año tras año de forma cada vez más diversa: plagio, fabricación o falsificación de datos, olvido o añadidura de un autor no consultado, firmas de complacencia, desmenuzamiento de las publicaciones, manipulaciones estadísticas, filtrado de referencias bibliográficas, etc. Todas estas derivas son motivo de rechazo de una parte de los manuscritos que nos llegan, por razones que nos dejan un regusto más bien amargo, pero nos permiten mantenernos firmes, ya que la integridad científica no se discute (Corvol, 2016).
Nuestro rumbo no ha cambiado. Defendemos el principio de una revista gratuita, accesible a todos, protegida de la dinámica del mercado editorial. Estamos orgullosos de pertenecer a un establecimiento que no se muerde la lengua ante revistas depredadoras que se alimentan de la deriva de la investigación científica. Y estamos especialmente contentos de constatar que los investigadores del Sur se movilizan igualmente contra estas prácticas depredadoras desastrosas, tan engañosas como condenables, a las que se encuentran particularmente expuestos, tal como revela este estudio mordaz, aunque sano, de Matumba et al. (2019).

Hace más de veinticinco años, el sociólogo canadiense Serge Larivée, autor de un informe sobre el fraude científico, ya había vislumbrado perfectamente las consecuencias nocivas de una ética científica negligente (Larivée et Baruffaldi, 1992): «quizás falta poco, especialmente en período de recesión, para que los contribuyentes, influidos por la cobertura periodística sensacionalista de algunos casos célebres, cuestionen el volumen presupuestario concedido a la investigación científica en tal o tal dominio, o incluso en su conjunto». Ello nos invita a velar todavía más atentamente por que, de conformidad con la misión de nuestro establecimiento y con el respeto a la ética que defendemos activamente, nuestra querida revista de Cirad se mantenga tan colaborativa como íntegra.

\section{Références bibliographiques Bibliographic references Referencias bibliográficas}

Corvol P., 2016. Bilan et propositions de mise en œuvre de la charte nationale d'intégrité scientifique. Rapport remis à Thierry Mandon, secrétaire d'État chargé de l'Enseignement supérieur et de la Recherche, 29 juin 2016, Paris, 63 p. http:// etico.iiep.unesco.org/fr/resource/bilan-et-propositions-demise-en-oeuvre-de-la-charte-nationale-dintegrite-scientifique

Harris M., Marti J., Watt H., Bhatti Y., Macinko J., Darzi A. W., 2017. Explicit bias toward high-income-country research: a randomized, blinded, crossover experiment of English clinicians. Health Affairs, 36 (11): 1997-2004. https://doi.org/10.1377/ hlthaff.2017.0773

Larivée S., Baruffaldi M., 1992. Les fraudes scientifiques. Rapport préliminaire. Université de Montréal, Conseil de recherche en sciences humaines du Canada, 239 p.

Matumba L., Maulidi F., Balehegn M., Abay F., Salanje G., Dzimbiri L., et al., 2019. Blacklisting or Whitelisting? Deterring Faculty in Developing Countries from Publishing in Substandard Journals. Journal of Scholarly Publishing, 50 (2): 83-95. https:// doi.org/10.3138/isp.50.2.01

Seglen P. O., 1997. Why the impact factor of journals should not be used for evaluating research. British Medical Journal, 314: 498-502. https://www.ncbi.nlm.nih.gov/pmc/articles/ PMC2126010/ 